\title{
RNA Transport Gene
}

National Cancer Institute

\section{Source}

National Cancer Institute. RNA Transport Gene. NCI Thesaurus. Code C54549.

A gene that encodes a protein which facilitates the transport of some form of RNA from one subcellular compartment to another. 